\title{
Hepcidin is described as the master regulator of iron: could its removal by CRRT lead to iron dysmetabolism in the critically
}

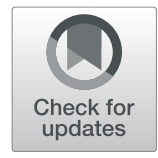
ill?

\author{
Patrick M. Honore*, Leonel Barreto Gutierrez, Luc Kugener, Sebastien Redant, Rachid Attou, Andrea Gallerani and \\ David De Bels
}

Litton et al. noted that many of the risk factors for iron deficiency are also risk factors for developing a critical illness, and consequently, iron deficiency is likely to be over-represented in critically ill patients [1]. Hepcidin is described as the master regulator of iron that determines the severity and duration of an iron-restricted state [1]. Insufficient hepcidin levels are central to iron overload while hepcidin excess leads to iron restriction [1]. A persistent state of iron dysmetabolism not only predisposes a vulnerable population to decreased erythropoiesis, but also has implications for the risk of nosocomial infection and critical illness-associated cognitive, neuromuscular, and cardiopulmonary dysfunction [1]. A recent cohort study of 807 critically ill patients with acute kidney injury (AKI) requiring renal replacement therapy (RRT) found that both higher plasma concentrations of catalytic iron and lower concentrations of hepcidin are associated with increased mortality [2]. A key question arising from this study is to what extent RRT contributes to iron dysmetabolism in critically ill patients. Fifty percent of critically ill patients develop AKI and 25\% require RRT [3]. Hepcidin and pro-hepcidin have molecular weights of $2700 \mathrm{Da}$ and $10,000 \mathrm{Da}$, respectively, and, therefore, may be removed by continuous RRT (CRRT), which uses membranes with a cut-off of 35,000 $\mathrm{Da}$ [4]. The protein-bound fraction of hepcidin is about $40 \%$ [4] which does not impede its elimination by convection or diffusion [5]. It has been demonstrated that

\footnotetext{
* Correspondence: Patrick.Honore@CHU-Brugmann.be

ICU Department, Centre Hospitalier Universitaire Brugmann, Brugmann

University Hospital, Place Van Gehuchtenplein, 4, 1020 Brussels, Belgium
}

maintenance dialysis with both super-flux polysulphone (PS) and acrylonitrile 69 (AN69) membranes similarly removed hepcidin [5]. Hemodialysis with PS membranes may achieve a high removal ratio of hepcidin by enhanced diffusion performance and an increased clearance of small molecule solutes, while AN69 membranes may remove hepcidin by adsorption [5]. Indeed, hepcidin can be removed by diffusion, while in the case of pro-hepcidin, convection is the main mechanism [5]. There are other factors to consider beyond RRT, and we should remain prudent regarding the therapeutic implications of RRT modalities at this early stage. The timing of iron administration in patients admitted to intensive care may also be a strong determinant of whether the benefits outweigh the risks [1]. In addition, other factors such as bleeding in anticoagulated patients or clotting of dialysis membranes may limit iron accumulation in critically ill patients. A better understanding of the epidemiology and outcomes of iron metabolism during critical illness is needed before designing interventional studies looking at iron metabolism during CRRT.

\section{Abbreviations \\ RRT: Renal replacement therapy; AKI: Acute kidney injury; Da: Daltons; CRRT: Continuous renal replacement therapies; PS: Polysulphone; AN69: Acrylonitrile 69}

\section{Acknowledgements \\ We would like to thank Dr. Melissa Jackson for critical review of the manuscript.}

\section{Authors' contributions}

$\mathrm{PMH}, \mathrm{SR}$, and DDB designed the paper. All authors participated in drafting and reviewing. The authors read and approved the final version of the manuscript.

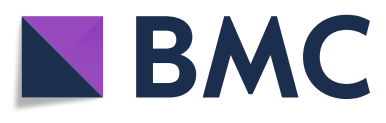

(c) The Author(s). 2020 Open Access This article is licensed under a Creative Commons Attribution 4.0 International License, which permits use, sharing, adaptation, distribution and reproduction in any medium or format, as long as you give appropriate credit to the original author(s) and the source, provide a link to the Creative Commons licence, and indicate if changes were made. The images or other third party material in this article are included in the article's Creative Commons licence, unless indicated otherwise in a credit line to the material. If material is not included in the article's Creative Commons licence and your intended use is not permitted by statutory regulation or exceeds the permitted use, you will need to obtain permission directly from the copyright holder. To view a copy of this licence, visit http://creativecommons.org/licenses/by/4.0/ The Creative Commons Public Domain Dedication waiver (http://creativecommons.org/publicdomain/zero/1.0/) applies to the data made available in this article, unless otherwise stated in a credit line to the data. 


\section{Funding}

None.

Availability of data and materials

Not applicable.

Ethics approval and consent to participate

Not applicable.

\section{Consent for publication}

Not applicable.

\section{Competing interests}

The authors declare to have no competing interests.

Received: 25 May 2020 Accepted: 15 September 2020

Published online: 22 September 2020

\section{References}

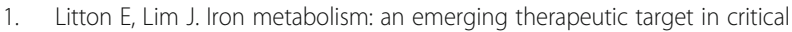
illness. Crit Care. 2019;23(1):81 https://doi.org/10.1186/s13054-019-2373-1.

2. Leaf DE, Rajapurkar M, Lele SS, Mukhopadhyay B, Boerger EAS, McCausland FR, et al. Iron, hepcidin, and death in human AKI. J Am Soc Nephrol. 2019; 30(3):493-504 https://doi.org/10.1681/ASN.2018100979.

3. Peters $E$, Antonelli M, Wittebole $X$, Nanchal R, François B, Sakr Y, et al. A worldwide multicentre evaluation of the influence of deterioration or improvement of acute kidney injury on clinical outcome in critically ill patients with and without sepsis at ICU admission: results from The Intensive Care Over Nations audit. Crit Care. 2018;22(1):188 https://doi.org/ 10.1186/s13054-018-2112-z.

4. Diepeveen LE, Laarakkers CM, Peters HPE, van Herwaarden AE, Groenewoud $\mathrm{H}$, IntHout J, et al. Unraveling hepcidin plasma protein binding: evidence from peritoneal equilibration testing. Pharmaceuticals (Basel). 2019;12(3):123 https://doi.org/10.3390/ph12030123.

5. Kuragano T, Furuta M, Shimonaka Y, Kida A, Yahiro M, Otaki Y, et al. The removal of serum hepcidin by different dialysis membranes. Int J Artif Organs. 2013;36(9):633-9 https://doi.org/10.5301/ijao.5000221.

\section{Publisher's Note}

Springer Nature remains neutral with regard to jurisdictional claims in published maps and institutional affiliations. 